\title{
Fermentation characteristics of persimmon wine by the mixed culture of Pichia anomala JK04 and Saccharomyces cerevisiae Fermivin cells
}

\author{
Soo-Jin Kwon ${ }^{1}$, Jun-Su Choi ${ }^{1}$, Soo-Hwan Yeo ${ }^{2}$, Heui-Dong Park ${ }^{1 *}$ \\ ${ }^{1}$ School of Food Science and Biotechnology, Kyungpook National University, Daegu 40566, Korea \\ ${ }^{2}$ Department of Agro-Food Resources, NAAS, RDA, Wanju 55365, Korea
}

\section{Pichia anomala JK04와 Saccharomyces cerevisiae Fermivin의 혼합발효에 의한 감와인의 발효 특성}

\author{
권수진 $^{1} \cdot$ 최준수 ${ }^{1} \cdot$ 여수환 $^{2} \cdot$ 박희동 $^{1 *}$ \\ ${ }^{1}$ 경북대학교 식품공학부, ${ }^{2}$ 농촌진흥청 국립농업과학원 농식품자원부
}

\begin{abstract}
Persimmon contains high levels of vitamins and phenolic compounds, as well as soluble solids, necessary for the fermentation of persimmon wine. Co-fermentation of persimmon wine was carried out using a mixed culture of Pichia anomala JK04, a Korean indigenous yeast that improves wine quality and flavor, and Saccharomyces cerevisiae Fermivin, an industrial wine yeast, in the following ratios: 9:1 (v/v), 5:5 (v/v), 1:9 (v/v) and 0:10 (v/v). During fermentation, the alcohol contents increased more slowly in samples of mixed culture than in samples of the single culture of $S$. cerevisiae Fermivin. The alcohol contents of all samples reached 12 13\% (v/v) after 15 days. All samples of the mixed culture showed greater variety in flavor and taste than $S$. cerevisiae Fermivin only. In the sensory evaluation, mixed culture samples had higher scores in terms of flavor and overall preference than the single culture samples. Therefore, $P$. anomala JK04 is thought to improve the wine flavor of Korean domestic persimmon wine.
\end{abstract}

Key words : co-fermentation, persimmon, Pichia anomala JK04, Saccharomyces cerevisiae Femivin, SPME

\section{서 론}

감(Diospyros kaki)은 동양이 원산지로서 한국, 중국 및 일본에 집중되어 있고 우리나라 기후 특성, 풍토에 적합하 여 대부분의 지역에서 널리 재배, 생산되고 있다(1). 감은 영양 가치가 매우 뛰어난 과일로서 다른 과일에 비해 수분 은 적은 편이며 당분 함량은 약 $14 \%$ 로 포도당, 과당으로 이루어져있다. 뿐만 아니라 200 280 mg/kg의 높은 비타민 $\mathrm{C}$ 와 무기질, 비타민 $\mathrm{A}$ 및 $\mathrm{B}$ 등이 풍부한 알칼리성 과일이다.

*Corresponding author. E-mail : hpark@knu.ac.kr Phone : 82-53-950-5774, Fax : 82-53-950-6772

Received 23 September 2015; Revised 5 October 2015; Accepted 7 October 2015.

Copyright (c) The Korean Society of Food Preservation. All rights reserved.
감에는 phenolics인 galic acid, catechin, epicatechin, epigallocatechin, catechin gallate 및 epigallocatechin gallate 등과 같은 기능성 phenolics가 다량 함유되어 있어 항산화 기능 뿐 아니라 조직의 손상방지, 노화방지, 심혈관계 질환 예방, 항암효과가 있는 것으로 알려져 있다(2-4)

이러한 영양학적 가치에도 불구하고 감 과실을 이용한 알코올 발효에 관한 것으로는 감을 이용한 와인 제조(5), 단감을 이용한 와인 제조(1), 청도반시를 이용한 와인 제조 (6), 대봉감 연시를 이용한 와인 제조(7) 등으로 감을 이용한 와인 제조에 관한 것은 아직 기초 연구 단계이며, 감와인 품질 향상에 관한 연구는 미미한 실정이라고 할 수 있다. 따라서 앞서 연구된 감와인 제조 연구에 더불어 품질 향상 을 위해 효모의 성질과 특징을 중점으로 배양효모를 선택하 여 와인의 품질을 상승시키는 연구가 필요하다.

예전부터 효모가 와인의 발전에 기여하는 기능성에 대하 
여 여러 연구가 이루어지고 있는 가운데 특히 nonSaccharomyces 와인효모의 발효 중 와인의 품질향상에 미 치는 영향에 대하여 많은 연구가 이루어지고 있다. 특히 Pichia anomala는 아세트산, 글리세롤, 에스테르, 아세토인 등과 같이 향미 증진과 같은 관능적 품질에 영향을 미치는 발효 화합물을 생성한다고 알려져 있다(8).

본 연구에서는 일반적으로 와인 발효에 주로 이용되고 있는 Saccharomyces cerevisiae Fermivin과 와인 제조에 있 어 향미를 좋게 하여 주질 향상에 도움이 되는 것으로 알려 져 있는 Pichia anomala JK04을 이용하여 이들의 첨가 비율 을 다르게 하였을 때, 감와인 발효 특성을 조사하여 주질 향상에 미치는 영향에 대하여 연구하였다.

\section{재료 및 방법}

\section{실험재료 및 균주}

감와인 발효에 사용한 원료 감은 2014년 경북 청도에서 수확한 청도 반시를 구입하여 사용하였으며, 필요에 따라 냉장, 냉동 보관하면서 사용하였다. 냉동된 상태의 감을 $2 \sim 3$ 일 동안 $4^{\circ} \mathrm{C}$ 냉장실에서 해동시킨 후에 착즙하여 5 개의 발효통에 $3 \mathrm{~kg}$ 씩 나누어 각 비율로 혼합된 효모를 접종 후 발효에 이용하였다.

\section{균주 및 종 배양 조건}

본 실험에서 사용한 균주는 경북대학교 식품공학과 미생 물공학실에 보관하고 있는 Pichia anomala JK04와 시판 와인효모인 Saccharomyces cerevisiae Fermivin(DSM Food Specialties, Delft, The Netherlands)을 사용하였다. YPD(1\% Bacto Yeast extract, 2\% Bacto Peptone, 2\% Bacto Dextrose) 액체배지에 효모를 접종한 후 회전진탕 배양기에서 $30^{\circ} \mathrm{C}$, $150 \mathrm{rpm}$ 으로 48시간 종 배양하여 알코올 발효를 위한 주모 로 사용 하였다.

\section{감와인의 제조}

감와인의 제조는 원료인 감을 세척, 제경 및 파쇄한 후 메타중아황산칼륨(potassium metabisulfite, $\mathrm{K}_{2} \mathrm{~S}_{2} \mathrm{O}_{5}$ ) 200 $\mathrm{ppm}$ 을 첨가하여 유해 미생물의 오염과 생육을 방지한 후 설탕을 가해 당도가 $24^{\circ} \mathrm{Brix}$ 가 되도록 하고 $3 \mathrm{~L}$ 발효용기에 담은 후 P. anomala JK04와 $S$. cerevisiae Fermivin의 종배양 액을 주모로 사용하여 4 구간의 실험을 진행하였다. 즉 감즙의 $5 \%$ 에 해당하는 균주를 종배양으로 하되 전체 $5 \%$ 의 종배양액 중 P. anomala JK04를 $90 \%, 50 \%, 10 \%, 0 \%$ 의 비율로 S. cerevisiae Fermivin과 함께 혼합 배양하여 감와인 의 알코올 발효 특성 및 품질 변화를 조사하였다. 발효는 $20^{\circ} \mathrm{C}$ 에서 진행시키고 이산화탄소의 발생이 줄고 알코올 농도가 최대치에 도달한 15 일째 발효를 종료하였다.

\section{감와인의 발효 특성 분석}

감와인의 $\mathrm{pH}$ 와 총산은 발효액을 원심분리 $(8,000 \mathrm{rpm}$, $10 \mathrm{~min}$ )한 후 상징액 $10 \mathrm{~mL}$ 을 취하여 자동적정장치(DL22 Food \& Beverage Analyzer, Mettler-Toledo AG Analytical Schwerzenbach, Switzerland)를 이용하여 측정하였다. 총산 은 $0.1 \mathrm{~N} \mathrm{NaOH}$ 로 적정하여 환산하여 나타내었다. 당도의 측정은 감와인 발효액을 원심분리 한 후 상징액을 취하여 굴절당도계(N-1a, ATAGO, Tokyo, Japan)를 사용하여 측정 하였다(9). 환원당 함량 측정은 dinitrosalicylic acid(DNS) 시약을 사용하여 비색 정량법으로 측정하였다(10). 상징액 $0.3 \mathrm{~mL}$ 에 DNS 시약 $1 \mathrm{~mL}$ 를 첨가하고 끓는물에서 5 분간 반응 시킨 후, 증류수 $7 \mathrm{~mL}$ 첨가하여 분광광도계(UV-1700, Shimazdu Co., Kyoto, Japan)를 사용하여 $550 \mathrm{~nm}$ 에서 흡광 도를 측정하고 포도당 표준곡선으로부터 환원당 함량을 환산하였다. 알코올 함량의 측정은 상징 액을 메스실린더에 $100 \mathrm{~mL}$ 취하여 증류 플라스크로 옮긴 후 메스실린더를 증류수 $15 \mathrm{~mL}$ 로 2회 세척 한 것을 혼합하여 증류하였다. 그 다음 증류액 $70 \mathrm{~mL}$ 을 받아 $100 \mathrm{~mL}$ 로 정용하여 국세청 주류분석법에 따라 1 차 증류 후 $15^{\circ} \mathrm{C}$ 에서 주정계를 이용하 여 측정하였다. 감와인의 hue와 intensity 값은 원심분리 한 상등액을 분광광도계(UV-1601, Shimazdu Co, Kyoto, Japan)로 $420 \mathrm{~nm}, 520 \mathrm{~nm}, 620 \mathrm{~nm}$ 에서 측정하여 $420 \mathrm{~nm}$ / $520 \mathrm{~nm}$ 을 hue 값으로, $420 \mathrm{~nm}+520 \mathrm{~nm}+620 \mathrm{~nm}$ 을 intensity 값으로 하였다.

\section{효모 생균수 측정}

감와인 발효과정 중의 생균수 변화는 멸균 생리식염수로 술덧을 적절한 배수로 희석하고 표준 평판 계수법을 이용하 여 YPD(1\% Bacto Yeast extract, 2\% Bacto Peptone, 2\% Bacto Dextrose) 고체배지에 도말 한 다음 $30^{\circ} \mathrm{C}$ 에서 48 시간 동안 배양하였다. 배양한 후 형성된 colony를 계수한 다음 colony forming unit $(\mathrm{CFU} / \mathrm{mL})$ 로 나타내었다. 집락수의 계산 은 확산집락이 없으며 1개의 평판 당 30 300개를 유효 범위 로 하였다(11).

\section{총 페놀성 화합물의 정량}

감와인의 총 페놀성 화합물의 함량 측정은 Folin-Denis법 (12)에 따라 비색 정량하였다. 상징액 $2 \mathrm{~mL}$ 와 $50 \%$ Folin-Ciocalteu 시약 $2 \mathrm{~mL}$ 를 첨가, 혼합 하여 3 분동안 실온 에서 방치한 다음 $10 \% \mathrm{Na}_{2} \mathrm{CO}_{3}$ 용액 $2 \mathrm{~mL}$ 첨가하여 실온에 서 1 시간 반응시켰다. 반응액을 분광광도계(UV-1700, Shimazdu Co.)를 이용하여 $700 \mathrm{~nm}$ 에서 흡광도를 측정하여 tannic acid를 표준물질로 작성한 표준곡선으로부터 총 페 놀성 화합물 함량을 환산하였다.

\section{색도 측정}

감와인의 색도는 발효가 완료된 시료의 상징액을 표준 
백색판 $(\mathrm{L}=97.78, \mathrm{a}=-0.39, \mathrm{~B}=+2.05)$ 으로 보정한 colorimeter (CM-3600A, Konical Minolta, Osaka, Japan)로 측정하여 Hunter's color value인 L(lightness), a(redness), b(yellowness) value로 나타내었다(9).

\section{유리당 및 유리산 함량}

감와인의 유리당과 유리산 조성 분석을 위해 시료를 적 절한 농도로 희석한 후 Sep-pack $\mathrm{C}_{18}$ cartridge와 membrane filter(Millex-HV $0.45 \mu \mathrm{m}$, Millipore Co., Bedford, USA)로 여과시킨 후 HPLC(Agilent Technologies Inc., California, USA)를 이용하여 분석하였다. 유리당 분석조건은 Table 1 과 같고 유기산 분석조건은 Table 2 와 같다.

Table 1. Operating conditions of HPLC for analyzing free sugar contents

\begin{tabular}{lc}
\hline \multicolumn{1}{c}{ Items } & Conditions \\
\hline Instrument & Agilent $1260 \mathrm{Infinity}$ \\
Column & zorbax Carbohydrate $(4.6 \mathrm{~mm} \mathrm{ID} \times 150 \mathrm{~mm}, 5 \mu \mathrm{m})$ \\
Column temp. & $35^{\circ} \mathrm{C}$ \\
Detector & Refractive Index Detector \\
Mobile phase & ACN/Water $(75: 25)$ \\
Flow rate & $1.4 \mathrm{~mL} / \mathrm{min}$ \\
Injection volume & $20 \mu \mathrm{L}$ \\
Running time & $20 \mathrm{~min}$ \\
\hline
\end{tabular}

Table 2. Operating conditions of HPLC for analyzing organic acid contents

\begin{tabular}{lc}
\hline \multicolumn{1}{c}{ Items } & Conditions \\
\hline Instrument & Agilent 1260 Infinity \\
Column & PL Hi-Plex $\mathrm{H}(\$ 7.7 \mathrm{~mm} \times 300 \mathrm{~mm}$, Agilent $)$ \\
Column temp. & $65^{\circ} \mathrm{C}$ \\
Detector & $\mathrm{UV}$ Detector \\
Mobile phase & $0.005 \mathrm{M} \mathrm{Sulfuric}$ acid \\
Flow rate & $0.6 \mathrm{~mL} / \mathrm{min}$ \\
Injection volume & $20 \mu \mathrm{L}$ \\
Running time & $20 \mathrm{~min}$ \\
\hline
\end{tabular}

\section{Malic acid 함량 분석}

Mcfeeters(13)의 연구에 따르면 HPLC 분석시 높은 농도 의 fructose는 보다 적은 농도의 malic acid의 정량을 방해할 수 있다고 한다. 정확한 malic acid 함량 분석을 위해 L-MALIC ACID ASSAY KIT(K-LMALR, Megazyme International Ireland Ltd., Bray Business Park, Bray, Co., Wicklow, Ireland)를 이용하여 측정하였다.

\section{휘발성 향기 성분 분석}

감와인의 휘발성 향기 성분은 SPME fiber(50/30 $\mu \mathrm{m}$ DVB/CAR/PDMS, Supelco, Bellefonte, PA, USA)를 사용하 여 head-space 분석법을 이용하여 분석하였다. 전처리 방법 으로는 headspace vial(20 mm, PTFE/silicon septum, magnetic cap)에 시료 $5 \mathrm{~mL}$ 와 $\mathrm{NaCl} 25 \%$ 를 첨가하여 완벽하 게 밀봉하고 $35^{\circ} \mathrm{C}$ 에서 자력교반기로 20 분동안 교반하여 시료와 headspace의 휘발성 성분이 평형이 이루게 되면 SPME fiber를 주입하여 40 분간 향기성분을 포집하였다 (14). 휘발성 향기 성분 분석을 위한 GC-MS 분석 조건은 Table 3 과 같다.

Table 3. GC-MS conditions for analysis of volatile compounds in persimmon wine

\begin{tabular}{lc}
\hline \multicolumn{1}{c}{ Items } & Conditions \\
\hline Instrument & Agilent $7890 \mathrm{~A}$ with Agilent $5975 \mathrm{C}$ inert XL MSD \\
Column & DB-WAX $(60 \mathrm{~m} \times 250 \mu \mathrm{m} \times \$ 0.25 \mathrm{~mm}$, Waters $)$ \\
Column temp. & $40^{\circ} \mathrm{C}(2 \mathrm{~min}) \rightarrow 220^{\circ} \mathrm{C}\left(2^{\circ} \mathrm{C} / \mathrm{min}\right) \rightarrow 240^{\circ} \mathrm{C}$ \\
Carrier gas & $\left(20^{\circ} \mathrm{C} / \mathrm{min}\right) \rightarrow 240^{\circ} \mathrm{C}(5 \mathrm{~min})$ \\
Injector temp. & $\mathrm{He}(1 \mathrm{~mL} / \mathrm{min})$ \\
Split ratio & $240^{\circ} \mathrm{C}$ \\
\hline
\end{tabular}

관능 평가

관능검사는 경북대학교 식품공학부 학생 중 본 실험에 관심이 있는 관능요원 총 10 명을 선발하여 5점 척도법(15) 으로 관능평가를 실시하였다. 관능평가 항목으로 색, 향기, 맛 및 전반적 기호도를 평가하여 1점(매우 나쁘다)으로부터 5점(매우 좋다)로 평가하였다.

\section{통계 처리}

모든 실험 결과는 3 회 반복 실험하여 그 결과 값을 평균과 표준편차로 나타내고 SAS 통계처리를 이용한 분산분석 (ANOVA)과 Duncan의 다중범위검증(Duncan's multiple range test, $\mathrm{p}<0.05)$ 으로 유의성을 검증하였다(16).

\section{결과 및 고찰}

\section{감와인의 발효 특성}

감와인의 발효과정 중의 당도 및 환원당 함량 변화는 Fig. 1 과 같다. 감와인의 당도는 초기 당도 $24^{\circ} \mathrm{Brix}$ 에서부터 발효가 진행됨에 따라 알코올로 전환되어 감소하는 것을 확인 할 수 있었으며 S. cerevisiae Fermivin 단독 발효구와 S. cerevisiae Fermivin과 P. anomala JK04의 혼합 첨가 발효 구의 경우 모두 발효 2 일째부터 당도가 감소하는 것을 확인 할 수 있었다. 일반적으로 포도주의 알코올 발효 후 최종 
당도는 7.0 7.4 Brix로 보고되어있는데(17,18) 본 감와인 연 구에서는 이보다 약간 높은 당도 값을 보였다. 이는 원료 구성성분 중 당의 성분 차이로 보여진다. 환원당 함량은 발효가 진행될수록 감소하여 발효종료시점에서 모든 구의 대부분의 환원당이 소비되어진 것으로 보인다. 발효과정 중의 $\mathrm{pH}$ 및 총산 변화는 Fig. 2 와 같다. 포도주를 비롯하여 과실주의 알코올 발효과정 중 $\mathrm{pH}$ 는 숙성, 저장 과정에서 잡균의 오염과 큰 관계가 있다고 보고되어 있다(19). 포도주

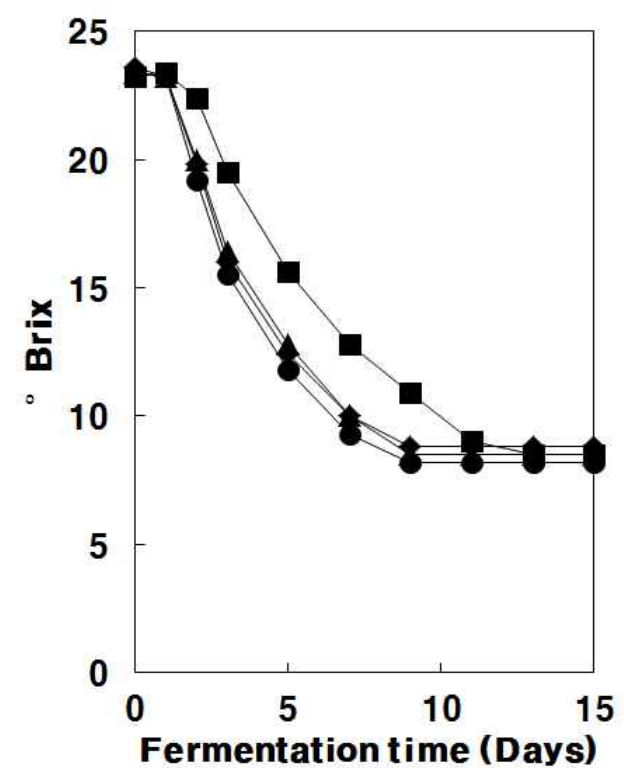

의 발효과정 중 권장되는 $\mathrm{pH}$ 의 범위는 3.2 3.5로서 이 범위 보다 높을 경우 잡균의 오염의 가능성이 있고 낮을 경우 신맛이 증가하여 제품의 품질에 나쁜 영향을 미치는 것으로 보고되어 있다(20). $\mathrm{pH}$ 변화는 모든 구에서 비슷한 경향으 로 발효초기 5.84에서 발효 종료 시 4.0 4.2로 감소하였는데 이는 포도주 발효과정보다 높은 $\mathrm{pH}$ 수치를 보였지만 기존 의 연구된 감와인 연구결과 $(6,7)$ 와 비슷한 결과를 나타냈다. 총산 함량 변화는 발효 7 9일째까지 급격히 증가하여 발효

Fig. 1. Changes in the soluble solid and reducing sugar contents during alcohol fermentation of persimmon with $P$. anomala JK04.

- S. cerevisiae Fermivin; $\square$, P. anomala JK04 90\%; $\boldsymbol{\Delta}$, P. anomala JK04 50\%; $\diamond$, P. anomala $\mathrm{JK} 0410 \%$.
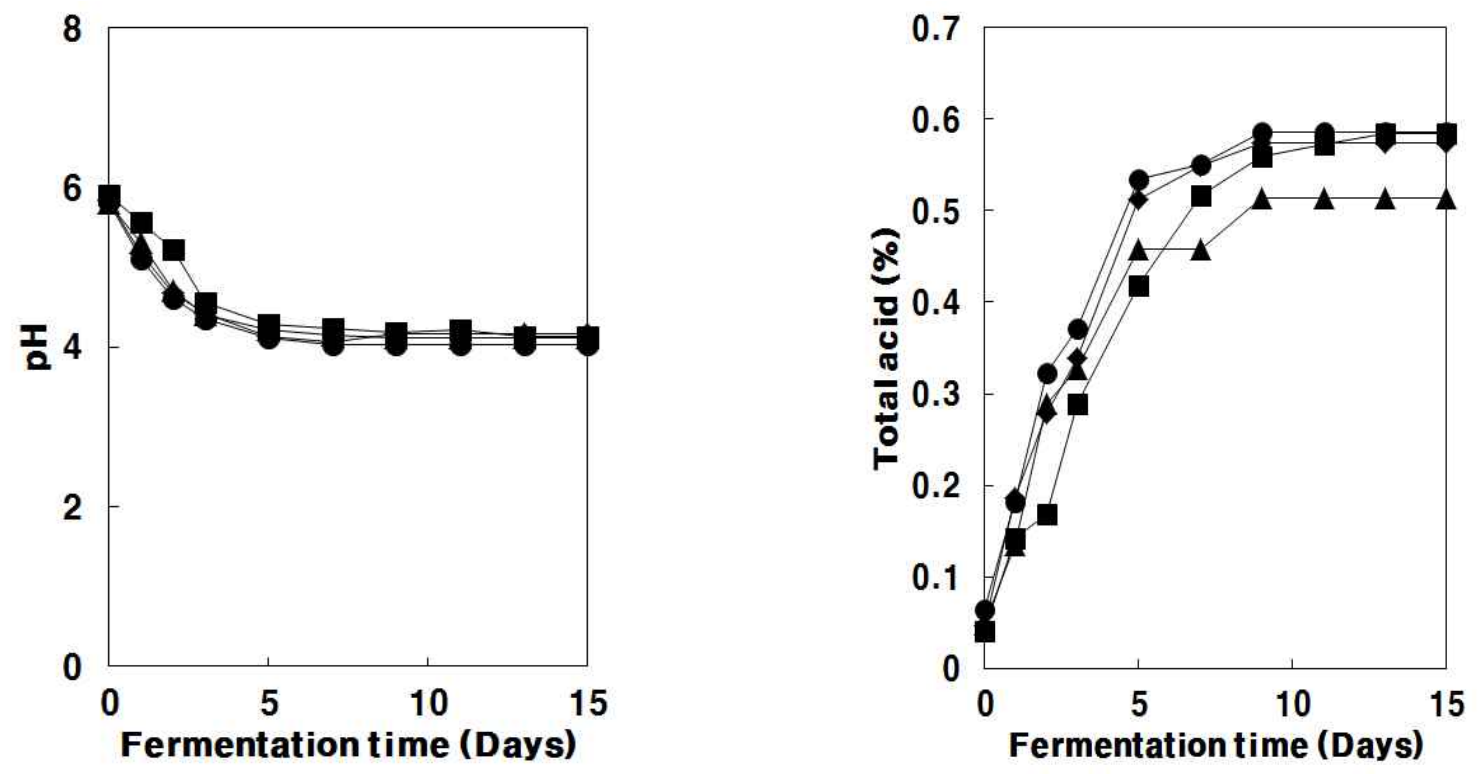

Fig. 2. Changes in the $\mathrm{pH}$ and total acid contents during alcohol fermentation of persimmon with $P$. anomala JK04.

- S. cerevisiae Fermivin; 口, P. anomala JK04 90\%; $\boldsymbol{\Delta}$, P. anomala JK04 50\%; $\diamond$, P. anomala $\mathrm{JK} 0410 \%$. 
종료 시 대부분 0.5 0.6\%를 나타내었다. 발효과정 중 알코 올 함량 측정은 Fig. 3과 같다. 효모의 대사와 밀접한 관련성 때문에, 과실류 와인의 알코올 농도는 효모균주의 발효능 을 보여주는 중요한 지표이다(21). 알코올 함량 변화는 $S$. cerevisiae Fermivin과 P. anomala JK04의 혼합 첨가 발효구 에서보다 S. cerevisiae Fermivin 단독 발효구에서 알코올 생성이 빨랐으며 발효 종료 시 알코올 농도는 12 13\%를 나타내었다.

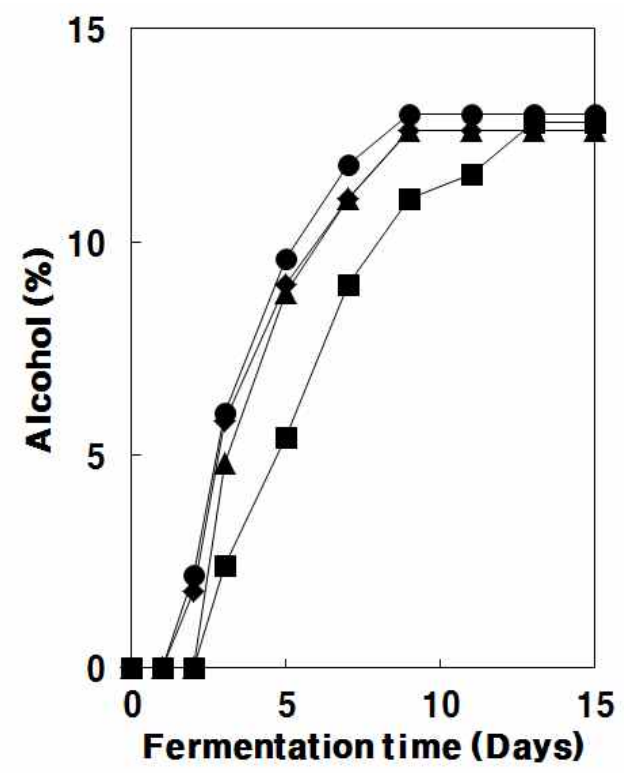

Fig. 3. Changes in the alcohol contents during alcohol fermentation of persimmon with $P$. anomala JK04.

, S. cerevisiae Fermivin; $\square, P$. anomala JK04 90\%; $\boldsymbol{\Delta}$, P. anomala JK04 50\%; P. anomala JK04 $10 \%$.

\section{효모 생균수 측정}

발효과정 중 생균수 변화는 Fig. 4와 같다. 발효 과정 중 생균수의 변화는 비슷한 양상으로 초기 약 $6.2 \mathrm{log}$ $\mathrm{CFU} / \mathrm{mL}$ 에서 시작하여 대체적으로 증가하다가 5일차 이후 로는 알코올 발효에 의해 알코올의 함량이 증가함에 따라 생균수도 일정하게 유지되는 양상을 나타내었다. $P$. anomala JK04 90\% 혼합 첨가 발효구에서는 환원당의 소비 속도 및 알코올 생성에서도 확인 알 수 있듯이 타 실험군에 비해 생균수의 변화가 더딤을 보여 안정적인 발효를 위해 S. cerevisiae Fermivin의 첨가 비율을 조금 높이는 것이 좋을 것으로 사료된다.

\section{총 페놀성 화합물의 정량}

발효과정 중 총 페놀성 화합물의 함량 변화는 Fig. 5와 같다. 페놀 화합물은 와인 색깔, 향미와 같은 관능적 품질뿐 만 아니라 항산화제로 작용하여 심장 질환 완화, 항암 작용 등에 도움이 된다고 보고되고 있다(22). 발효 초기에 약 $0.058 \mathrm{mg} / \mathrm{mL}$ 에서 약간 감소하는 경향을 나타내었지만 발

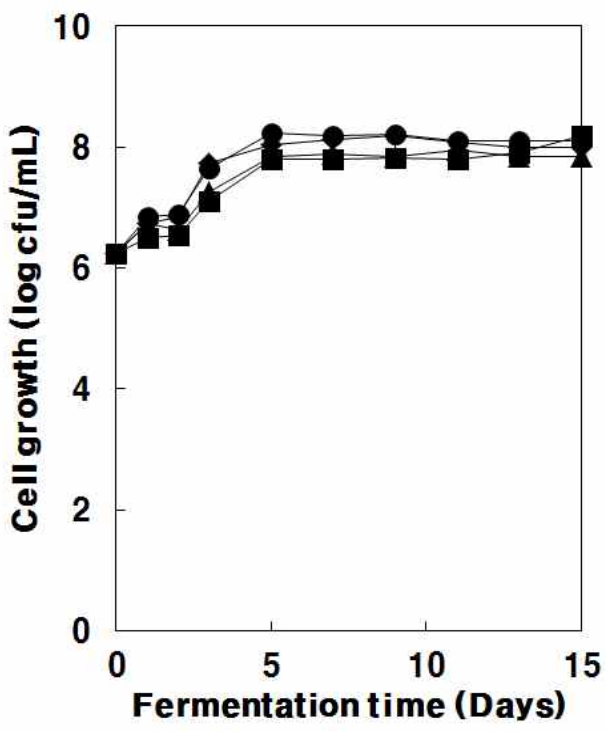

Fig. 4. Changes in the viable count during alcohol fermentation of persimmon with $P$. anomala JK04.

Q, S. cerevisiae Fermivin; $\square$, P. anomala JK04 90\%; $\boldsymbol{\Delta}$, P. anomala JK04 50\%; P. anomala JK04 $10 \%$.

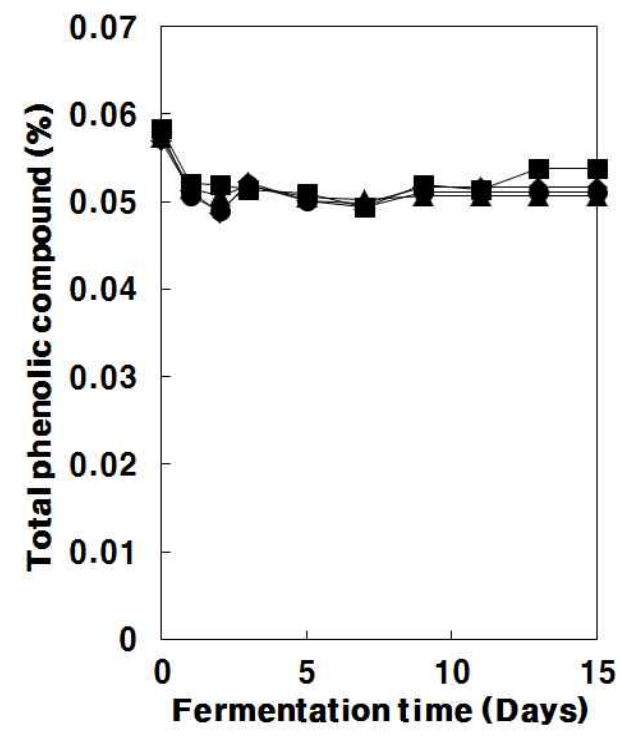

Fig. 5. Changes in the total phenolic compound contents during alcohol fermentation of persimmon with $P$. anomala JK04.

Q, S. cerevisiae Fermivin; $\mathbf{\square}$, P. anomala JK04 90\%; $\boldsymbol{\Delta}$, P. anomala JK04 50\%; P. anomala JK04 $10 \%$.

효 중반부터 다시 증가하여 발효 종료시 약 $0.05 \mathrm{mg} / \mathrm{mL}$ 를 유지하였다. 이는 알코올 발효가 진행됨에 따라 감에서 탄 닌, 색소 등과 같은 페놀성 화합물이 추출된 것으로 보이며, 기존의 감와인 연구에서 총 페놀성 화합물이 0.05 0.07 $\mathrm{mg} / \mathrm{mL}$ 로 보고된 것과 비교할 때 약간 낮거나 유사한 수치 를 보였다(1,7). P. anomala JK04의 첨가 비율이 높은 실험 군일수록 총페놀성 화합물의 함량이 높은 것으로 보이며 생리활성 물질생성이 좋은 것으로 사료된다. 


\section{Hue and intensity}

발효과정 중 hue와 intensity 변화는 Fig. 6 과 같다. 일반적 으로 레드와인은 $420 \mathrm{~nm}$ 파장에서는 플라보노이드와 탄닌 등의 황색 색소성분, $520 \mathrm{~nm}$ 파장에서는 안토시아닌과 같 은 적색 색소성분, $620 \mathrm{~nm}$ 파장에서는 청색의 안토시아닌 이 주된 성분(23)으로 스펙트럼은 $520 \mathrm{~nm}$ 에서 최고치를 보이고 $420 \mathrm{~nm}$ 에서 최저치를 나타내며 hue value는 값이 낮을수록 붉은 빛의 와인으로 광택, 갈변정도에 영향을 주 며 intensity vaule는 값이 높아질수록 갈변의 진행과 관련이 있는데, 감와인에서는 $420 \mathrm{~nm}$ 에서 최고치, $520 \mathrm{~nm}$ 에서 최 저치를 보였다. 이는 감의 플라보노이드와 탄닌 등의 황색 색소성분으로 인한 결과로 보여진다. hue value는 대부분의 구에서 발효 1 일차 이후로 증가하다가 다시 감소하여 발효 종료 시 4 5의 값을 나타내었고, intensity value는 발효초기 0.5 의 값에서 점차 감소하여 발효 종료 시까지 $0.1 \sim 0.2$ 의 값을 유지하였다.

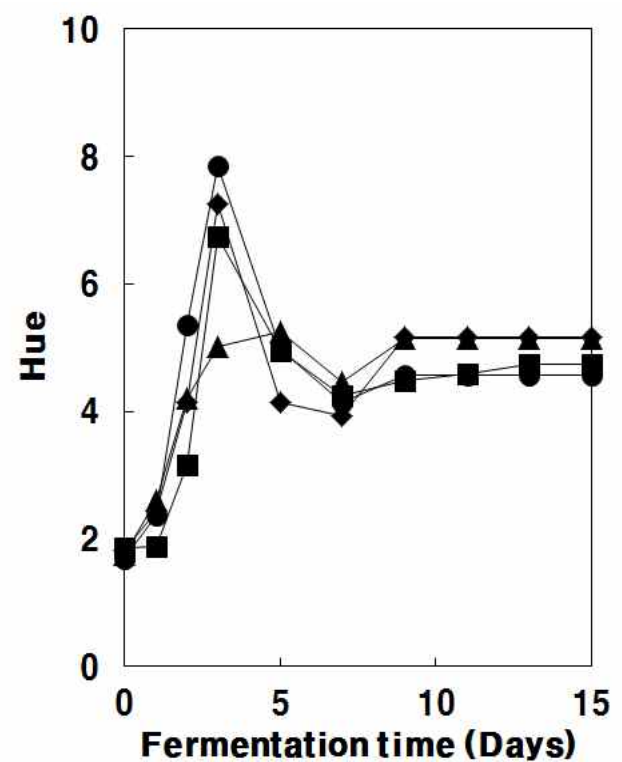

Table 4. Hunter's color values of persimmon wines after fermentation with mixed culture

\begin{tabular}{cccc}
\hline \multirow{2}{*}{ Yeast strain } & \multicolumn{3}{c}{ Hunter's color values } \\
\cline { 2 - 4 } & $\mathrm{L}$ & $\mathrm{a}$ & $\mathrm{b}$ \\
\hline JK04 90\% & \multicolumn{1}{c}{$58.99 \pm 0.01^{\mathrm{c} 2)}$} & $0.50 \pm 0.02^{\mathrm{a}}$ & $2.75 \pm 0.01^{\mathrm{c}}$ \\
JK04 50\% & & & \\
JK04 $10 \%^{3)}$ & $50.59 \pm 0.03^{\mathrm{a}}$ & $-0.17 \pm 0.02^{\mathrm{b}}$ & $3.68 \pm 0.02^{\mathrm{a}}$ \\
Fermivin & $60.81 \pm 0.12^{\mathrm{b}}$ & $-0.28 \pm 0.02^{\mathrm{c}}$ & $3.32 \pm 0.03^{\mathrm{b}}$ \\
\hline
\end{tabular}

${ }^{1)} \mathrm{JK} 04$, Fermivin=9:1; JK04, Fermivin=5:5; JK04, Fermivin=1:9.

${ }^{2)}$ The values were expressed as mean $\pm \mathrm{SD}(\mathrm{n}=3)$. Different letters within the same column indicate significant difference $(\mathrm{p}<0.05)$.

\section{유리당 및 유기산 함량}

감와인의 유리당 함량 결과는 Table 5 와 같다. 보당에 사용된 sucrose은 완전히 소비되어 검출되지 않았고 glucose

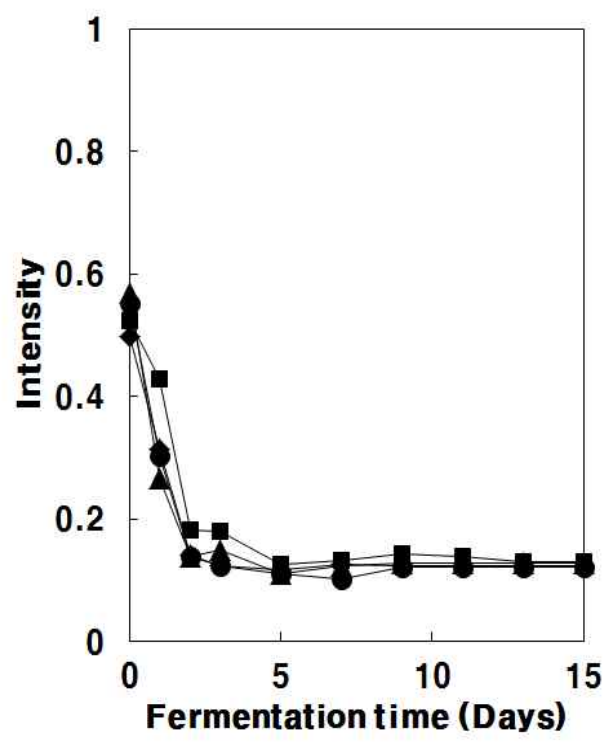

Fig. 6. Changes in the hue value and intensity value during alcohol fermentation of persimmon with $P$. anomala JK04.

- S. cerevisiae Fermivin;

口, P. anomala JK04 90\%;

A, P. anomala JK04 50\%;

P. anomala $\mathrm{JK} 0410 \%$.

\section{색도측정}

발효종료 후 $\mathrm{L}, \mathrm{a}, \mathrm{b}$ value는 Table 4과 같다. 색차는 와인 의 품질을 평가하는 중요한 요소일 뿐 아니라 숙성정도를 예측할 수 있는 지표가 될 수 있다(24). L value의 경우 모든 구에서 약 59 61의 수치를 나타내어 맑게 청징된 상태로 볼 수 있으며 a value의 경우에는 대부분의 구에서 0 에 가까 운 (-)값을 나타낸 것으로 보아 녹색과 적색 중간 상태의 색을 나타내었다. b value에서는 약 1.5 3.7의 수치로 연한 황색계열을 보였다. P. anomala JK04의 첨가 비율이 높은 실험군일수록 적색도와 황색도의 경우 증가하는 경향을 보였다.
Table 5. Free sugar content of persimmon wines after fermentation

$(\mathrm{g} / \mathrm{L})$

\begin{tabular}{cccc}
\hline Yeast strain & Sucrose & Glucose & Fructose \\
\hline JK04 90\% & $\mathrm{ND}^{2)}$ & $8.346 \pm 1.994^{\mathrm{a} 3)}$ & $13.448 \pm 2.712^{\mathrm{a}}$ \\
JK04 50\% & $\mathrm{ND}$ & $6.679 \pm 3.408^{\mathrm{a}}$ & $15.016 \pm 2.266^{\mathrm{a}}$ \\
JK04 10\% & $\mathrm{ND}$ & $4.396 \pm 1.468^{\mathrm{a}}$ & $14.303 \pm 1.241^{\mathrm{a}}$ \\
Fermivin & $\mathrm{ND}$ & $2.694 \pm 1.500^{\mathrm{a}}$ & $6.745 \pm 1.083^{\mathrm{b}}$ \\
\hline
\end{tabular}

${ }^{1)} \mathrm{JK} 04$, Fermivin=9:1; JK04, Fermivin=5:5; JK04, Fermivin=1:9.

${ }^{2} \mathrm{ND}$, not detected.

${ }^{3)}$ The values were expressed as mean $\pm \mathrm{SD}(\mathrm{n}=3)$. Different letters within the same column indicate significant difference $(\mathrm{p}<0.05)$. 
Table 6. Organic acid contents of persimmon wines after fermentation

$(\mathrm{g} / \mathrm{L})$

\begin{tabular}{ccccc}
\hline Yeast strain & Citric acid & Tartaric acid & Malic acid & Succinic acid \\
\hline JK04 90\% & $0.665 \pm 0.003^{\mathrm{c} 2)}$ & $0.224 \pm 0.009^{\mathrm{c}}$ & $0.058 \pm 0.029^{\mathrm{d}}$ & $0.969 \pm 0.012^{\mathrm{d}}$ \\
JK04 50\% & $1.544 \pm 0.010^{\mathrm{a}}$ & $0.525 \pm 0.011^{\mathrm{a}}$ & $1.006 \pm 0.008^{\mathrm{a}}$ & $1.066 \pm 0.014^{\mathrm{b}}$ \\
JK04 10\% & $1.387 \pm 0.010^{\mathrm{b}}$ & $0.372 \pm 0.009^{\mathrm{b}}$ & $1.533 \pm 0.027^{\mathrm{c}}$ & $1.037 \pm 0.011^{\mathrm{c}}$ \\
Fermivin & $1.540 \pm 0.011^{\mathrm{a}}$ & $0.380 \pm 0.002^{\mathrm{b}}$ & $2.161 \pm 0.011^{\mathrm{b}}$ & $1.227 \pm 0.008^{\mathrm{a}}$ \\
\hline
\end{tabular}

1) JK04, Fermivin=9:1; JK04, Fermivin=5:5; JK04, Fermivin=1:9.

${ }^{2)}$ The values were expressed as mean $\pm \mathrm{SD}(\mathrm{n}=3)$. Different letters within the same column indicate significant difference $(\mathrm{p}<0.05)$.
과 fructose의 경우에는 모든 구에서 미량 검출되었다. 발효 과정 중 효모의 당 이용성이 sucrose, glucose, fructose 순으 로 glucose와 fructose가 검출된 것은 효모의 당 이용성에 관련이 있다고 판단된다. 감와인의 유리산 함량 결과는 Table 6과 같다. 감와인 주요 유기산으로는 citric acid, tartaric acid, succinic acid이 검출되었다. 와인 제조 시 citric acid은 맛에 중요한 성분으로 신선한 향을 증가시켜준다고 보고되어 있는데(7), P. anomala JK04 50\% 혼합 첨가 발효 구에서 $1.544 \mathrm{~g} / \mathrm{L}, S$. cerevisiae Fermivin 단독 발효구에서 $1.540 \mathrm{~g} / \mathrm{L}$ 로 가장 높은 값을 나타내었다. 과실주의 산미에 미치는 영향은 총산도가 동일하였을 때는 malic > tartaric

Table 7. Volatile aromatic compounds in persimmon juice and wines

(Unit: peak area value/1.000)

\begin{tabular}{|c|c|c|c|c|c|c|c|}
\hline \multirow{2}{*}{ Compound number } & \multirow{2}{*}{ Name } & \multirow{2}{*}{ Odor description } & \multicolumn{5}{|c|}{ Strains } \\
\hline & & & Juice & JK04 90\% ${ }^{1)}$ & JK04 50\% & JK04 10\% & Fermivin \\
\hline \multicolumn{8}{|l|}{ Alcohols } \\
\hline 1 & 1-Propanol & fusel & $\mathrm{ND}^{2)}$ & 4652 & 3119 & 3203 & 4933 \\
\hline 2 & Isobutyl alcohol & vegetal, herbaceous & 3827 & 51273 & 25102 & 22039 & 26822 \\
\hline 3 & 1-Hexanol & floral & 9806 & 1274 & $\mathrm{ND}$ & ND & $\mathrm{ND}$ \\
\hline 4 & Benzeneethanol & fusel & 1764 & 7658 & 9918 & 17255 & 13998 \\
\hline 5 & Isoamyl alcohol & grassygreen & 75046 & 259583 & 262888 & 292449 & 424440 \\
\hline 6 & Leaf alcohol & grassygreen & 654 & ND & ND & ND & $\mathrm{ND}$ \\
\hline \multicolumn{8}{|l|}{ Esters } \\
\hline 7 & Ethyl acetate & fruity & $\mathrm{ND}$ & 96871 & 33395 & 28467 & 28384 \\
\hline 8 & Methyl acetate & apple, banana & $\mathrm{ND}$ & 803 & ND & ND & $\mathrm{ND}$ \\
\hline 9 & Ethyl hexanoate & fruity, apple, solvent & $\mathrm{ND}$ & 13226 & 21052 & 32601 & 28894 \\
\hline 10 & Ethyl decenoate & sweet, fatty nut-like & $\mathrm{ND}$ & ND & 2119 & 1554 & $\mathrm{ND}$ \\
\hline 11 & Ethyl 9-decenoate & fruty, fatty & $\mathrm{ND}$ & $\mathrm{ND}$ & 2075 & 2066 & 5517 \\
\hline 12 & Methylsalicylate & wintergreen, peppermint & 8087 & 9020 & 6100 & 9972 & 4882 \\
\hline 13 & Ethyl salicylate & wintergreen & 11095 & $\mathrm{ND}$ & $\mathrm{ND}$ & ND & $\mathrm{ND}$ \\
\hline 14 & Phenethyl acetate & fruity, floral, rose & $\mathrm{ND}$ & 674 & 786 & 2737 & 3402 \\
\hline 15 & Isoamyl acetate & banana, pear & $\mathrm{ND}$ & 9379 & 18687 & 34031 & 44780 \\
\hline 16 & Ethyl N-methylcarbamate & pineapple, pear & 1991 & ND & ND & ND & $\mathrm{ND}$ \\
\hline 17 & Ethyl n-heptadecanoate & fruity, sweetish, apple & $\mathrm{ND}$ & 862 & ND & ND & $\mathrm{ND}$ \\
\hline 18 & Ethyl butyrate & pineapple & ND & 813 & 1479 & 1956 & 1666 \\
\hline \multicolumn{8}{|l|}{ Aldehydes } \\
\hline 19 & Acetaldehyde & & $\mathrm{ND}$ & 3416 & 2453 & 1863 & 2168 \\
\hline 20 & Hexanal & & 3920 & ND & ND & ND & ND \\
\hline 21 & 4-Propylbenzaldehyde & & 484 & ND & ND & ND & $\mathrm{ND}$ \\
\hline \multicolumn{8}{|l|}{ Acids } \\
\hline 22 & Acetic acid & sour & 1010 & 13730 & 1597 & 1724 & 1204 \\
\hline 23 & Octanoic acid & sweaty & $\mathrm{ND}$ & 899 & 1994 & 2907 & 2333 \\
\hline
\end{tabular}

${ }^{1)}$ JK04, Fermivin=9:1; JK04, Fermivin=5:5; JK04, Fermivin=1:9.

${ }^{2)} \mathrm{ND}$, not detected. 
> citric의 순으로 산미가 강하고, 동일 $\mathrm{pH}$ 에서는 malic > citric > tartaric의 순으로 산미가 강하다 $(25,26)$. 따라서 malic acid의 함량은 와인의 산미를 결정할 뿐만 아니라 malic acid가 적정량 이상 존재하게 되면 풋내를 증가시키기 도 한다(19). 감와인의 malic acid 함량은 $S$. cerevisiae Fermivin 단독 발효구에서 $2.1613 \mathrm{~g} / \mathrm{L}$ 로 가장 높은 수치를 나타내었고, $P$. anomala JK04 첨가량이 증가할수록 malic acid 함량이 감소하여 P. anomala $\mathrm{JK} 0490 \%$ 혼합 첨가 발효 구에서 $0.058 \mathrm{~g} / \mathrm{L}$ 로 가장 낮은 값을 나타내어 부드럽고 신선 한 맛을 보였다.

\section{휘발성 향기 성분}

감즙 및 알코올 발효가 끝난 4종의 감와인 휘발성 향기성 분을 분리·동정하여 확인된 휘발성 향기성분 및 상대적 농도는 Table 7에 표시하였다. 와인의 향기성분은 와인의 품질을 결정하는데 중요한 요소이며, 이를 이루는 물질은 esters, aldehydes, ketones, terpenes, acids, alcohols, sulfur compounds 등이 있으며 이들 서로 다른 화합물의 복합적 작용으로 인해 향기성분이 형성된다(27). 정량적 관점에서 감와인에서 휘발성성분의 가장 많은 부분을 차지하는 것은 알코올류이다. 과실류 와인발효시 다양한 효모들은 고급알 코올의 종류와 농도에서 상당히 차이가 있음에 기여한다 (28). P. anomala JK04 90\% 혼합첨가구의 경우 1-propanol, isobutyl alcohol, 1-hexanol, benzeneethanol, isoamyl alcohol 5 종의 알코올류가 검출되었고 특히, 허브향기를 내는 isobutyl alcohol이 S. cerevisiae Fermivin 단독 발효구에 비 해 큰 폭을 차지하였다.

에스테르 화합물은 주로 발효 과정에서 acyl-CoA 의 도 움으로 효소적 에탄올 분해작용으로써 반응하는 전구체들 로부터 합성된다(29). P. anomala JK04 90\% 혼합첨가구의 경우 ethyl acetate, methyl acetate, ethyl hexanoate, methylsalicylate, phenethyl acetate, isoamyl acetate, ethyl n-heptadecanoate, ethyl butyrate 8 종의 에스테르류가 검출 되었으며 이는 S. cerevisiae Fermivin 단독 발효구의 에스테 르 화합물과 달리 apple, banana향을 띄는 methyl acetate와 fruity, sweetish, apple향을 내는 ethyl n-heptadecanoate 2종 이 더 검출되었다. 이러한 결과는 P. anomala JK04가 다양 한 종류의 에스테르합성능력이 있다는 것을 보여준다. Acid류의 경우 P. anomala JK04 90\% 혼합첨가구의 경우 octanoic acid가 S. cerevisiae Fermivin 단독 발효구에 비해 상대적으로 적게 검출되었다. $\operatorname{Park}(30)$ 의 보고에 따르면 octanoic acid는 함량이 높을수록 sweaty향의 불쾌취를 유발 하는데 P. anomala JK04의 첨가 비율이 높을수록 octanoic acid의 함량이 낮은 것으로 보아 이취를 감소시킬 수 있는 효과가 있는 것으로 보인다. Rojas 등(8)의 연구결과와 같이 $P$. anomala $\mathrm{JK} 04$ 가 향미 증진과 같은 관능적 품질에 영향을 미치는 발효 화합물을 생성한다는 것을 확인할 수 있으며,
S. cerevisiae Fermivin과의 혼합발효를 통해 빠르고 안정된 발효와 다양한 향미를 가지는 우수한 와인개발 가능성을 보여준다.

Table 8. Sensory scores of persimmon wines after alcohol fermentation

\begin{tabular}{ccccc}
\hline Yeast strain & Color & Flavor & Taste & $\begin{array}{c}\text { Overall } \\
\text { preference }\end{array}$ \\
\hline JK04 90\% & $2.60 \pm 0.52^{\mathrm{C} 2)}$ & $3.10 \pm 0.74^{\mathrm{ab}}$ & $3.60 \pm 0.70^{\mathrm{a}}$ & $3.60 \pm 0.84^{\mathrm{ab}}$ \\
JK04 50\% & $3.50 \pm 0.85^{\mathrm{b}}$ & $3.80 \pm 0.90^{\mathrm{a}}$ & $3.40 \pm 1.17^{\mathrm{a}}$ & $3.90 \pm 0.88^{\mathrm{a}}$ \\
JK04 10\% & $3.80 \pm 0.63^{\mathrm{ab}}$ & $2.80 \pm 0.79^{\mathrm{b}}$ & $2.80 \pm 1.03^{\mathrm{a}}$ & $3.30 \pm 0.82^{\mathrm{ab}}$ \\
Fermivin & $4.30 \pm 0.82^{\mathrm{a}}$ & $2.80 \pm 0.79^{\mathrm{b}}$ & $2.40 \pm 0.70^{\mathrm{a}}$ & $2.80 \pm 0.79^{\mathrm{b}}$ \\
\hline
\end{tabular}

${ }^{1)} \mathrm{JK} 04$, Fermivin=9:1; JK04, Fermivin=5:5; JK04, Fermivin=1:9.

${ }^{2)}$ The values were expressed as mean $\pm \mathrm{SD}(\mathrm{n}=10)$. Different letters within the same column indicate significant difference $(\mathrm{p}<0.05)$.

\section{관능 평가}

발효 종료 후 관능요원 10 명을 대상으로 한 감와인의 관능 평가 결과는 Table 9 와 같다. 향기에 대한 평가의 경우 P. anomala JK04 90\%와 50\% 혼합 첨가 발효구에서 각각 $3.60,3.40$ 점의 점수로 $S$. cerevisiae Fermivin 단독 발효에 비해 높은 점수를 얻었는데 이것은 P. anomala JK04의 다양 한 향기성분 생성능에 부합하는 결과이다. 이 영향으로 인 해 맛과 종합적 기호도의 경우에서도 $P$. anomala JK04를 혼합 첨가한 모든 구에서 S. cerevisiae Fermivin 단독 발효에 비해 높은 점수를 얻어 P. anomala JK04와 기존 와인 발효 균주와의 혼합발효를 통하여 우수한 와인의 개발이 가능함 을 확인하였다.

\section{요 약}

본 연구에서는 와인제조에 있어 향미 증진과 같은 품질 향상에 도움이 된다고 알려진 Pichia anomala JK04와 일반 적으로 와인 양조에 주로 이용되고 있는 Saccharomyces cerevisiae Fermivin을 혼합 발효하여 감와인의 발효 특성을 비교하였다. 감와인의 발효특성 결과 발효 종료 시 대부분 의 실험구에서 $\mathrm{pH} 4.0 \sim 4.2$, 총산 $0.5 \sim 0.6 \%$ 를 나타내었다. 당도와 환원당 함량 변화는 발효가 진행될수록 점차 감소하 여 S. cerevisiae Fermivin 단독 발효구와 P. anomala JK04 혼합 첨가 발효구에서 발효 종료시점에서 대부분의 당이 소비되었다. 최종 알코올 함량은 $S$. cerevisiae Fermivin 단독 발효구와 S. cerevisiae Fermivin과 P. anomala JK04의 혼합 첨가 발효구에서 알코올 생성이 빨랐으며 발효 종료 시 모든 구의 알코올 농도는 12 13\%를 나타내었다. 각 첨가구 의 총 페놀성 화합물 함량은 $0.05 \mathrm{mg} / \mathrm{mL}$ 로 초기 페놀성 화합물 함량과 비슷한 수준을 유지하였다. 감와인의 hue value는 발효 초기에 비해 증가하여 4 5의 값을 나타내었 
고, intensity value는 발효초기 0.5 의 값에서 점차 감소하여 발효 종료 시까지 0.1 0.2의 값을 유지하였으며 휘발성 향 기성분의 경우 P. anomala JK04의 첨가 비율이 높을수록 S. cerevisiae Fermivin 단독발효구 보다 다양한 알코올류, 에스테르류가 생성되었다. 관능검사 결과에서 향기와 맛의 평가에서 P. anomala JK04를 첨가한 모든 혼합 발효구에서 S. cerevisiae Fermivin 단독발효구 보다 높은 점수를 얻었다.

\section{감사의 글}

본 연구는 2015년 농촌진흥청 어젠다 과제(PJ009439022015) 의 연구비 지원에 의해 수행되었으며 이에 감사드립니다.

\section{References}

1. Bae SM, Park KJ, Kim JM, Shin DJ, Hwang YI, Lee SC (2002) Preparation and characterization of sweet persimmon wine. J Korean Soc Agric Chem Biotechnol, 45, 66-70

2. Achiwa Y, Hibasmi H, Katsuzaki H, Iami K, Komiya $\mathrm{T}$ (1997) Inhibitory effects of persimmon (Diospyros kaki) extract and related polyphenol compounds on growth of human lymphoid leukemi cells. Biosci Biotechnol Biochem, 61, 1099-1101

3. Teisedre PL, Landrault N (2000) Wine phenolics : contribution to dietary intake and bioavailability. Food Res Int, 33, 461-467

4. Kim HJ, Woo HJ (1998) In vitro anticancer activity of flavonoids as the functional foods materials. Korean $\mathbf{J}$ Lab Anim Sci, 14, 87-91

5. Ann YG, Pyun JY, KIM SK, Shin CS (1999) Studies on persimmon wine. Korean J Food Nutr, 12, 455-461

6. Lee SW, Lee OS, Jang SY, Jeong YJ, Kwon JH (2006) Monitoring of alcohol fermentation condition for 'chenogdobansi' astringent persimmon (Diospyros kaki T.). Korean J Food Preserv, 12, 490-494

7. Joo OS, Kang ST, Jeong CH, Lim JW, Park YG, Cho KM (2011) Manufacturing of the enhances antioxidative wine using a ripe daebong persimmon (Dispyros kaki L). J Appl Biol Chem, 54, 2, 126-134

8. Rojas V, Gil JV, Pinaga F, Manzanares P (2001) Studies on acetate ester production by non-Saccharomyces wine yeasts. Int J Food Microbiol, 70, 283-289

9. AOAC (2000) Official method of analysis 17th Ed. Association of official analytical chemists, Washington
DC, p 210-219

10. Ahmed H (2004) Principles and reations of protein extraction, purification and characterization. CRC Press, London, England, p 350-352

11. Korean Food \& Drug Administration (2010) Food code. KFDA, Seoul, Korea, 10-3-25

12. Amerine MA, Ough CS (1980) Methods for analysis of musts and wine. Wiley \& Sons, New York, USA, p 176-180

13. Mcfeeters RF, Thomson RL, Fleming HP (1993) Malic acid in cucumber juice and fermentation Brines in the presence of interrupting fructose. J Food Sci, 58, 4, 832-834

14. Torrens J, Riu-Aumatell M, Lopez-T E, Buxaderas S (2004) Volatile compounds of red and white wines by headspace-solid-phase microextraction using differnts fibers. J Chromatogr Sci, 42, 310-316

15. Lawless H, Heymann H (1988) Sensory evaluation of food : principles and practices. Chapman and Hall, San Francisco, California, USA, p 149-174

16. SAS (2004) SAS/STAT 9.3 user's guide. SAS Institute Inc, Cary, NC, USA, p 313-383

17. Hong YA, Park HD (2013) Role of non-Saccharomyces yeasts in Korean wines produced from Campbell Early grapes : potential use of Hanseniaspora uvarum as starter culture. Food Microbiol, 34, 207-214

18. Kim MS, Yeo SH, Park HD (2013) Fermentation characteristics of Campbell Early wine by indigenous Saccharomyces cerevisiae yeasts with resistance to potassium metabisulfite and a high sugar concentration. Korean J Food Preserv, 20, 744-750

19. Park WM, Park HG, Rhee SJ, Kang KI, Lee CH, Yoon KE (2004) Properties of wine from domestic grape, Vitis labrusca cultivar. Campbell' Early, fermented by carbonic maceration vinification process. Korean J Food Sci Technol, 36, 773-778

20. Park WM, Park HG, Rhee SJ, Lee CH, Yoon KE (2002) Suitability of domestic grape, cultivar Campbell' Early, for production of red wine. Korean J Food Sci Technol, 34, 590-596

21. Romano P, Fiore C, Paraggio M, Caruso M, Capece A (2003) Function of yeast species and strains in wine flavour. Int J Food Microbiol, 86, 169 - 180

22. Koh KH (1999) Healthy characteristics of wine. Korean J Food Ind Nut, 4, 20-25

23. Sinleton VL, Trousdale EK (1992) Anthocyanin-tannin interactions explaining differences in polymeric phenols 
between white and red wines. Am J Enol Vitic, 43, 63-70

24. Ribereau-Gayon P, Glories Y, Maujean A, Dubourdieu D (2006) Handbook of enology, the chemistry of wine: stabilization and treatments, Wiley \& Sons, New york, 2, p 129-185

25. Zoecklein BW, Fugelsang KC, Gump BH, Nury FS (1990) Production wine analysis. Chapman and Hall, New York, USA, p 129-168

26. Amerine MA, Roeseler EB, Ough CS (1965) Acids and the acid taste I-The effect of $\mathrm{pH}$ and titratable acidity. Am J Enol Viticult, 16, 29-37

27. Vas G, Găl L, Harangi J, Dobŏ (1998) Determination of volatile aroma compounds of blaufrankisch wines extracted by solid-phase microextraction. J Chromtogr Sci, 36, 505-510

28. Vilanova M, Sieiro C (2006) Contribution by Saccharomyces cerevisiae yeast to fermentative flavour compounds in wines from cv. Albariňo. J Ind Microbiol Biotechnol, 33, 929 - 933

29. Swiegers JH, Pretorius IS (2005) Yeast modulation of wine flavor. Adv Appl Microbiol, 57, 131 - 176

30. Park NY (2000) Dynamic changes in flavor-related components of polygonatum odoratum root as affected by steaming and roasting. $\mathrm{Ph} \mathrm{D}$ Thesis. Kyungpook National University, Daegu, Korea 